\title{
GATHERINGS OF JEWISH ARTISTS IN INTERWAR LITHUANIA
}

Summary. The main subject of this paper is the Jewish artists of interwar Lithuania and their efforts to unite. It analyses the aspirations of Jewish artists to unite into groups, to represent and present their art, and to maintain their national identity. The article introduces the main organisers, participants, circumstances and goals of the artists' gatherings. It discusses three cases: the cultural policy pursued by National Jewish Council's Section of Culture at the institutional level; Jewish artists who gathered on a social basis; and the Art Gallery of Neemiya Arbit Blatas as a unique exhibition space in inter-war Lithuania, which mainly exhibited the works of Jewish artists. The paper focuses not on the artistic legacy or its value, but rather on the processes of cultural life of Jewish artists in interwar Lithuania.

Keywords: Jewish art, art gatherings, Jewish art exhibitions, Lithuania, Berlin, interwar period.

Throughout the interwar period, the representatives of the largest national minority culture in interwar Lithuania balanced between autonomy and integrity. On the one hand, there was their relentless striving to preserve their national identity, and on the other hand, efforts to integrate into the general culture of the country: it is in this context that the activities of Jewish artists dominate the historiography of interwar Lithuanian art. ${ }^{1}$ As early as 1921, Jewish artists entered the Lithuanian cultural field. Jokūbas Mesenbliumas (Jacques Missene, 18941933) became the first Jewish artist to participate in the Lithuanian Art Exhibition, where he showed 10 paintings. $^{2}$ Throughout the rest of the interwar period, Jewish artists were active participants in the country's artistic life. However, the knowledge of Jewish artists as a distinct community has only been explored through the stylistics and subject matter of their artworks, ${ }^{3}$ as well as the artists' debut performances in Kaunas fine art life. ${ }^{4}$ All the studies carried out so far have presented Lithuanian Jewish art between the two world wars as a fragmented activity of individual artists - artists who seem to be unrelated to each other. The knowledge of Jewish artistic life lags far behind, for example, that of the literary world: not only in terms of the cognitive aspect, but also in terms of the very processes - the literary environment had more collective gatherings of Jews. Sometimes the literati were joined by artists. This manifests in the artistic cover designs of almanacs and collections, in some cases in periodicals, and in other cases in the illustrations. We can mention Issachar Ber Ryback (1897-1935), who designed the covers and emblem for the "Likht" (Yiddish for "light") publishing house, Benzion Zukerman, who worked with the "Yidish" publishing house, and Yudl Sherenzon (1896-1941/1942), the author of the artistic design of the one-time literary newspaper "Kveytn"5 (Yiddish for "flowers") and several book covers of the "Mir Aleyn" (Yiddish for "we ourselves/only") publishing house, along with Zale Beker (1896-1941/1942), who created the emblem and publication covers for the "Mir Aleyn" and the cover of the almanac "Shlyakhn"6 (Yiddish for "road/public road"), and some others. However, the artists' own efforts to unite or to show the need to unite have not been analysed. It is not necessarily about the high-quality artistic legacy, but rather about its historical value and the narrative (testimony) it brings. 
NATIONAL JEWISH COUNCIL'S SECTION OF CULTURE

The idea of a separate presentation of Lithuanian Jewish art was born as early as 1920. The National Jewish Council's Section of Culture was the first to set this goal: it tried to organise an exhibition of Lithuania's Jewish artists in Berlin. Surviving letters by the organisers, preserved in the Lithuanian Central State Archives (LCVA), ${ }^{7}$ have helped us to reconstruct the course of the exhibition preparatory works. In 1920, the National Jewish Council was established as the autonomous main governing body of the Union of Jewish Communities - a kind of parliament that managed the affairs of Jews' life. Its creation was one of the commitments under Lithuania's National Minorities Rights Project that was presented at the Paris Peace Conference in 1919. The Council was headed by a chairman and its interests were represented at the state level by the Minister of Jewish Affairs. ${ }^{8}$ The main task of the Cultural Section, which was established under the Council in 1920, was the organisation of the education system, but it did not leave culture behind. The formation of the Lithuanian Jewish professional art field was initiated and organised by the two main initiators and organisers of the exhibition in Berlin: Dr. Leo Deutschlander (1889-1935), the head of the Cultural Section, and Bencion Zuckerman (Cukerman) (1890-1944), a Vilnius-based artist. The educator and writer Leo Deutschlander, who was posted to the Eastern Front during World War I as a German army officer, mediated communication between German officials and local Jews, and organised a network of Yavne schools in Lithuania. When the war was over, the National Jewish Council invited him to head the Cultural Section and to help set up a Jewish education system. He was joined by Vilnius-born Zuckerman, a well-known and successful painter who received his artistic education at the Vilnius Drawing School from 1906 to 1909/1910; later he studied in Berlin and Paris. From 1917 to 1919, while living in Petrograd (now St. Petersburg) and Moscow, Zuckerman took an active part in Jewish cultural life. In 1919 he returned to Vilnius, where he still managed to organise his exhibition "Pictures of Palestine"("Palestinos vaizdai").
However, the pogrom in Vilnius in April 1919, the anti-Semitic sentiments of Polish society, and the critical situation of the Jews in Vilnius in 1920 forced him to abandon his hometown and retreat to Kaunas, where the situation of the Jews was far more favourable. The contacts and close friendships with the Jewish intelligentsia that he had established in Russia helped him to adapt quickly to an unfamiliar city. The "young, talented artist, remarkable for having had exhibited his works in various countries", and whose works "gave a prominent place to the life and nature of Lithuania, ${ }^{10}$ presented himself to the Kaunas public with a personal exhibition from 14 to 24 November of 1920 in the Cultural Section Hall (apartment) of the Jewish People's Council (1, Tolstojaus St., now L. Sapiegos St.). ${ }^{11}$ The exhibition featured paintings of Lithuanian landscapes and the Jewish quarter of Vilnius, as well as graphic works such as miniatures, calligraphy, bookplates and book illustrations, etc. ${ }^{12}$

Both of the two main organisers of the exhibition had relatively little knowledge of Lithuania, and even less of Kaunas. Therefore, they used their own knowledge and resources to organise the exhibition. The coordination of the exhibition, which was to take place in Berlin in January to February 1921, started at the end of 1920 . The representatives of the Cultural Section corresponded on organisational matters with the Honorary Consul of Lithuania in Berlin, Beno Giršavičius (Hirschowitz, ? -1930), and the artist Joseph Budko (1888-1940). Budko, as a friend and fellow student of Zuckerman's at the Vilnius Drawing School (1902-1909), got a request to contribute to the organisation of the exhibition and the accompanying literary evening, which would feature performances by the actors Aleksandr Asro (1888-1963) and Sonia Alomis (1896-1976), members of the Vilner Troupe, who had moved to Berlin from Vilnius. ${ }^{13}$ There were also propositions to involve the painter and graphic artist Hermann Struck (1876-1944) as participant in the exhibition. Like Deutschlander, Struck served in the German army during the First World War, and was a translator and Jewish Commissioner on the Eastern Front. While living in Vilnius and Kaunas, he produced a number of drawings and graphic works depicting 
the life of the Jews of Kaunas and Vilnius regions, and was in close contact with local intellectuals. ${ }^{14}$ The organisation of the exhibition in Berlin was his desire to take advantage of the still vivid interest in the romanticised and exotic Jewish culture of Eastern Europe. The correspondence asserted that the artworks had been prepared for shipment, but did not specify how many or which works were selected. ${ }^{15}$ Unfortunately, the organisation of the exhibition was interrupted. In 1921, Deutschlander resigned as chairman of the Cultural Section, and soon afterwards Zuckerman left for abroad; the work they had begun was not continued.

The Berlin art exhibition was to present young, emerging artists alongside the experienced creators Zuckerman, Budko and Struck: those were Sholom Zelmanovich (Šolomas Zelmanovičius) and Sara Goršenaitè (Gorschein), who lived in Lithuania, as well as two Berlin-based artists, Feiga Blumberg and Peisakh Chieskes. ${ }^{16}$ We can only speculate why the organisers chose only these artists and not, for example, Max Band (1900-1974), Issai Kulvianski (1892-1970), who had been studying in Berlin since 1920, or Meyer Miron Kodkine (1887-1940), who arranged his solo exhibition in the apartment of the Jewish Gymnasium 21 July 1921 on the occasion of opening of the Kaunas Jewish Community Council. ${ }^{17}$ It is difficult to identify the selection criteria and to say whether those were present at all. Was the selection based solely on acquaintanceship, or was it based on political views? In any case, it is clear that the support of the National Jewish Council's Section of Culture at the beginning of their creative path must have been a significant milestone in the creative career of each of the artists, and it is therefore worth taking a closer look at the biography and work of each of them.

The National Jewish Council's Section of Culture paid special attention to the sculptor Sara Goršenaite, not only by including her in an exhibition in Berlin, but also by mediating in the matter of her art studies in Berlin, and by organising her solo exhibition in Kaunas in 1923. Sara Goršenaite ${ }^{18}$ was born in 1897 in Švenčionys, ${ }^{19}$ where she later studied in the Jewish Gymnasium, and then attended nurses training courses, possibly in Russia. Her first acquaintance with sculpture was related to the leisure activities of her father Aba (Abel) Goršen (1860-1933). Goršen, who had a traditional yeshiva and cheder education, was a respected member of the Jewish community in Švenčionys, worked for a period of time in a bank, and later served as a mediator in the transportation of goods from Jewish merchants in Švenčionys to traders in Vilnius. Goršen was also known for both his artistic and technical talents: in his spare time, he created tombstones, worked with wood and painted signboards. His daughter, who was often nearby, became familiarised with various sculpting materials and techniques at an early age. The sculptor's connection to traditional Jewish culture and art, although not reflected in her work, was an important accent in the construction of her romanticised image as an artist. After the First World War, Goršenaitè returned to Lithuania and worked as a nurse in the Panevezzys Jewish Hospital. An article accompanying the sculptor's first exhibition in Kaunas in 1923 specifies that it was the sculpture or sculptural group of "Mephistopheles", which she saw in the hospital, that awakened her desire to create her own artworks. ${ }^{20} \mathrm{~A}$ new phase in the sculptor's life began when a "Lithuanian sculptor learned about her creative work and came to see her artworks"21 and, impressed by her competence, helped Goršenaitè to arrive at a newly opened art school in Kaunas. Thus, in 1920 Goršenaitè became one of the first to attend the drawing courses. The National Jewish Council's Section of Culture also took an interest in the young Jewish artist. In 1922-1923, Goršenaitè went to Berlin to study, but due to financial difficulties, she returned to Lithuania a year later and resumed her job in a hospital. In the autumn of 1923, the Culture Section helped Goršenaitè to organise her solo sculpture exhibition the first personal exhibition by a female artist and the first sculpture exhibition in independent Lithuania. The small exposition featured 25 sculptural objects. An article by Vytautas Bičiūnas reviewing her exhibition stresses the lack of uniformity of style and the insufficient number of exhibits. ${ }^{22}$ On the other hand, the critic acknowledges the artist's talent and courage. We can only access the sculptor's works through reproductions in the pages of the periodical press, 
which does not provide enough information for a general discussion of her oeuvre ${ }^{23}$ (Fig. 1-3).

Compared with S. Goršenaite, who had not yet had any experience, the other artist chosen by the Culture Section, Feiga Blumberg, had already achieved a lot. Born in Kaunas in 1894, Feiga ((later Yuli) Blumberg Kopman, 1894-1964) had been based in Berlin since 1919. Probably, like most Jews, she was forced to emigrate to Russia during the First World

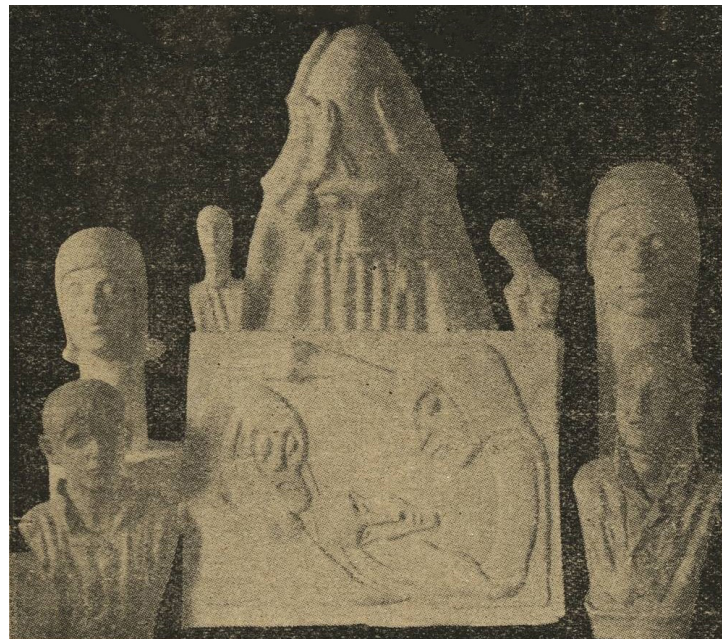

Fig. 1. Composition of Sara Gorschein's artwork from exhibition in Kaunas in 1923, Vispe, 1924, p. 36 (epaveldas.lt)

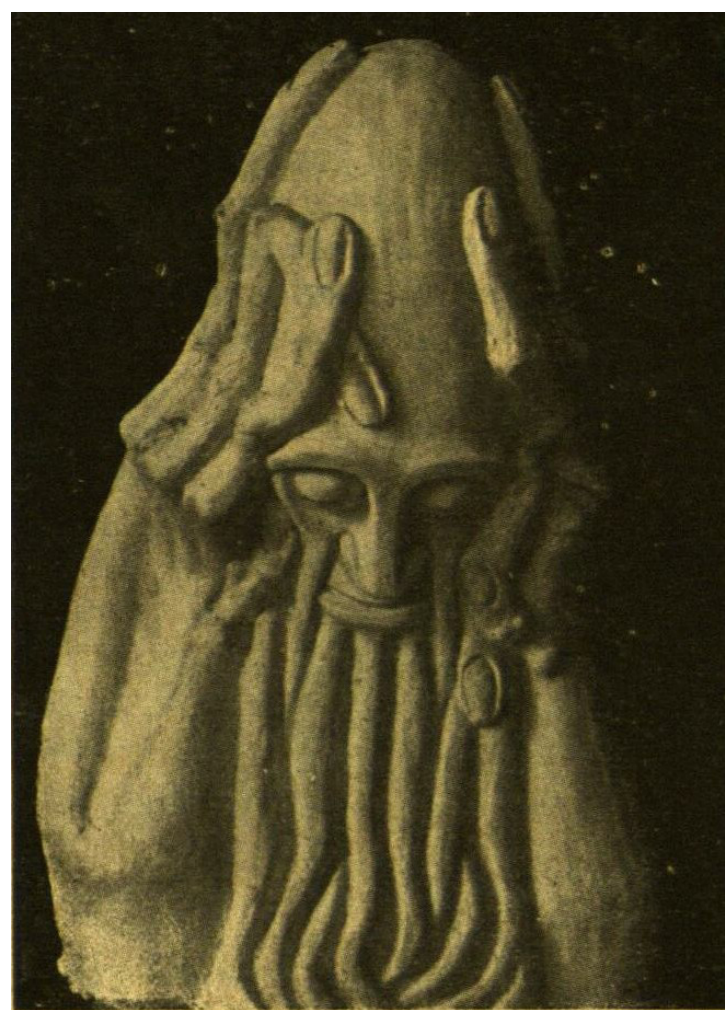

Fig. 2. Sara Gorschein. Composition, 7 meno dienos, 1929, issue No. 46, p. 10 (epaveldas.lt)
War. According to unconfirmed reports, she studied in Moscow during the war and later continued her education in Berlin. ${ }^{24}$ Blumbergaite, a painter and graphic artist, was a member of the Freie Secession group, together with the well-known expressionists of the time Max Liebermann, Oskar Kokoschka, Emil Nolde, Wilhelm Lehmbruck, Franz Marc and others, and her artworks were exhibited in the association's group exhibitions. In 1924, when the association's activities were disrupted, Blumbergaite, with the help of the well-known gallerist and collector J. B (Jsrael Ber) Neumann (1887-1961). ${ }^{25}$ Neumann left for the United States in 1925, living in New York, where she successfully continued her career as an artist. ${ }^{26}$ The artist's style has been obviously influenced by German Expressionism, her artworks featuring the contrasting black lines typical of the Primitivists, and characterised by combinations of large forms. Blumbergaitė worked mainly on portraits and still lifes with flowers.

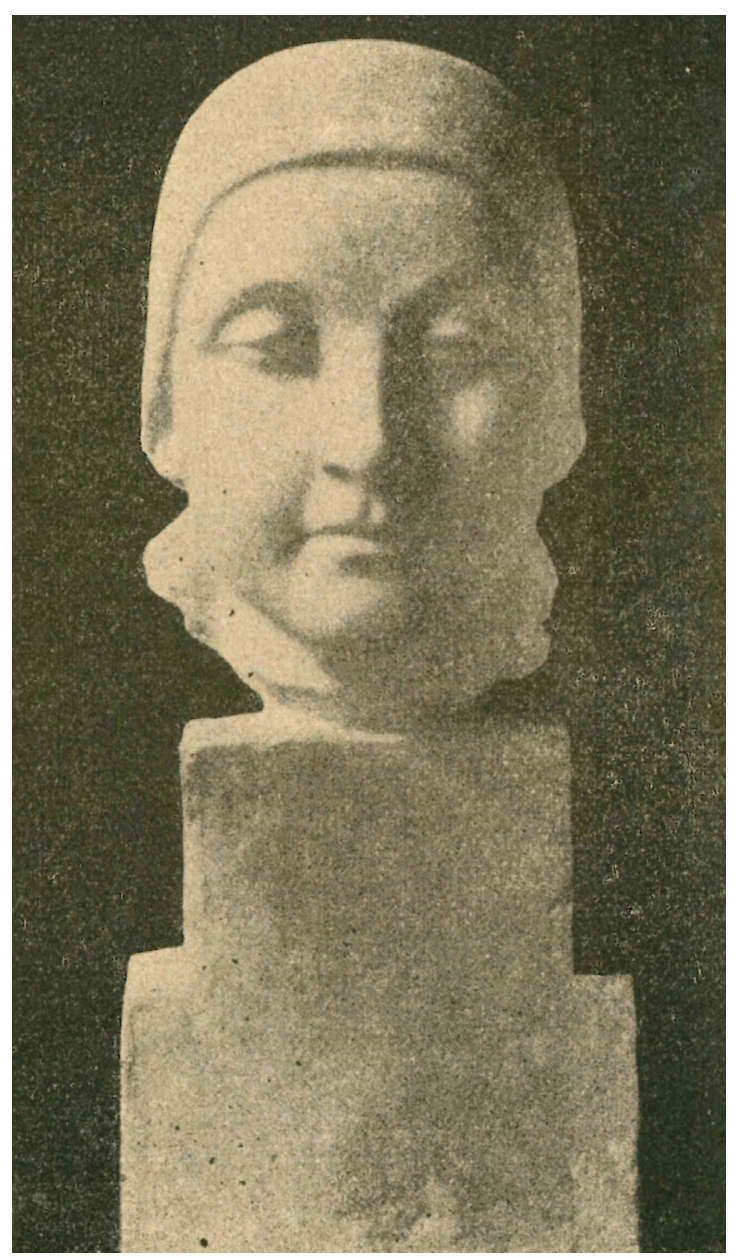

Fig. 3. Sara Gorschein. Woman's head, Mir aleyn, Kaunas, 1930, insert between p. 36-37 (epaveldas.lt) 
The third young artist whose work the Culture Section found worthy of representing Lithuanian art was Sholom Zelmanovich (1898-c.1944). The artist moved from Vilnius to Kaunas in 1920, and, like Zuckerman, left Vilnius probably because of the steadily worsening situation of the Jews in the city. The artist, who had worked in various theatres since 1915, joined the State Theatre in Kaunas around 1921 as an assistant stage designer, a post he held until 1939. In 1922, he joined the activities of the Jewish Acting Studio. The theatre and stage design shaped the artist's painting style. Zelmanovich was not an active participant in the artistic life of interwar Lithuania: he held a solo exhibition in 1928, and took part in several other group exhibitions, but did not join any of the later gatherings of Jewish artists.

Least known is information about Peisakh Chieskes, whom the National Jewish Council proposed for an exhibition in Berlin. Traces of his oeuvre survive only in applied graphic art, in the field of book covers. He designed the cover of "Arum Shtal" ("Around the Stable"), a novel by Peysakh Markus published by "Likht" publishing house and printed in Berlin in 1923 (Fig. 4). Another example of the artist's work is the cover of the 1939 yearbook-calendar of the Society for Jewish History and Ethnography. ${ }^{27}$

In 1924, the Ministry of Jewish Affairs and the post of Minister without Portfolio were abolished (completely abolished in 1925), and the activities of the National Jewish Council also ended. A number of public and cultural figures moved to other countries. The work of the National Jewish Council's Section of Culture ceased before it could even gain momentum. The Cultural Section chose to represent Lithuanian Jewish art in Berlin as its main direction of activities and to present art creators individually, rather than to unite artists to create a common autonomous national culture.

\section{FIRST EXHIBITION OF JEWISH ARTISTS}

Another attempt to unite the work of Lithuanian Jewish artists was crowned with success: in 1929, Kaunas hosted the first exhibition of Lithuanian Jewish art. In the introduction, the exhibition catalogue presents the organisers as "Lithuania's Jewish

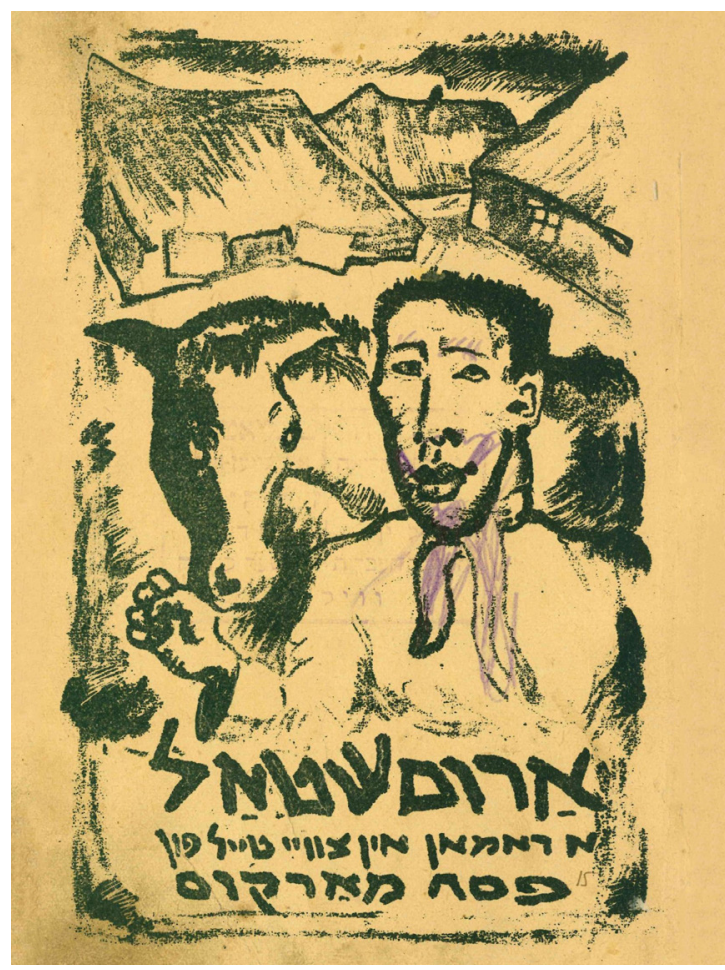

Fig. 4. P. Chieskes. Peisakh Markus. Arum Shtal. Cover. Berlin: Likht, 1923. Martynas Mažvydas National Library of Lithuania

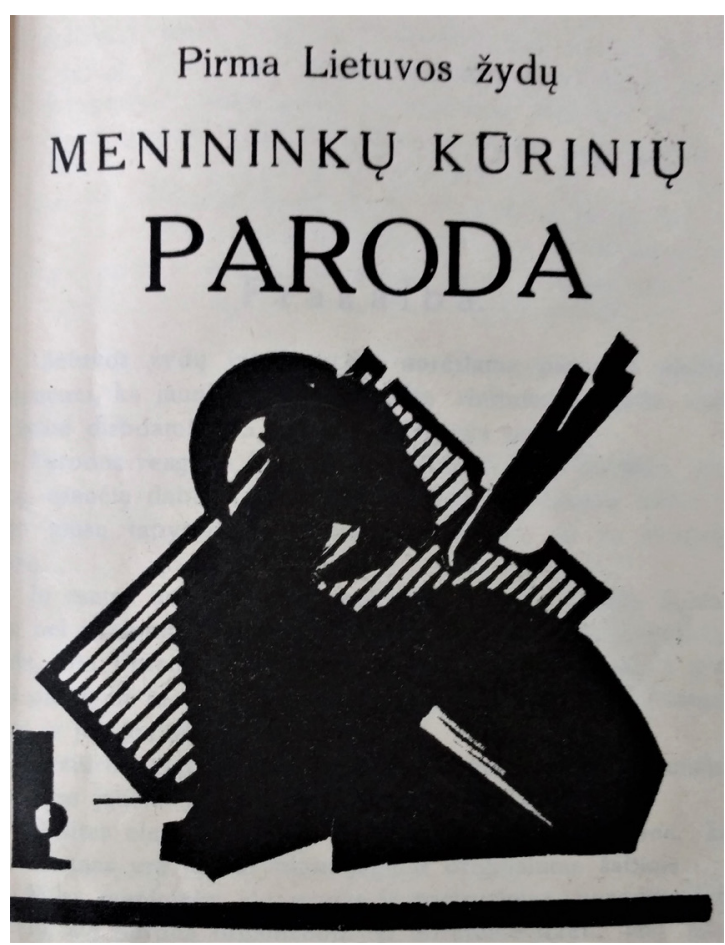

Fig. 5. Catalogue of the first Jewish exhibition. Fragment of a cover. Kaunas, 1929. The Library of Kaunas University of Technology

intelligentsia"28 (Fig. 5). The organisers of the exhibition, which opened in the apartment of the Jewish Gymnasium (14 Maironio St.), intended to "show 
the wider public that which young artists have created with deep seriousness and love, working willingly but quietly". ${ }^{29}$ The exhibition featured 16 artists living or temporarily residing in the country at the time - 4 sculptors and 12 painters - and presented 105 works of art (Fig. 6). The artists represented different stylistic trends and a wide range of educational backgrounds: Kaunas School of Art students Zale Beker (1896-1941/1942), Max Leiba Ginsburg (1909-?), Yitskhok Yofe, Yakovas Lipshits, J. Šerenzon, and artists who had been educated in other countries: in France - Hirsh Markus, in Belgium - Sholom Feigenzon (1881-1942(?)), in Italy - Levinsonas, Jokūbas (Jankelis) Kazlauskas (Jacques Koslowsky), in Germany - S. Goršenaitè, and the participants whose "only teacher was Lithuania's nature and its moods": ${ }^{30}$ David (Alter) Kagan, R. Kacienè, D. Labkauskas, I. Lipšès, Vidgeravičius (Fig. 7). We could not find any information on the education of the painter Moses Tsesler.

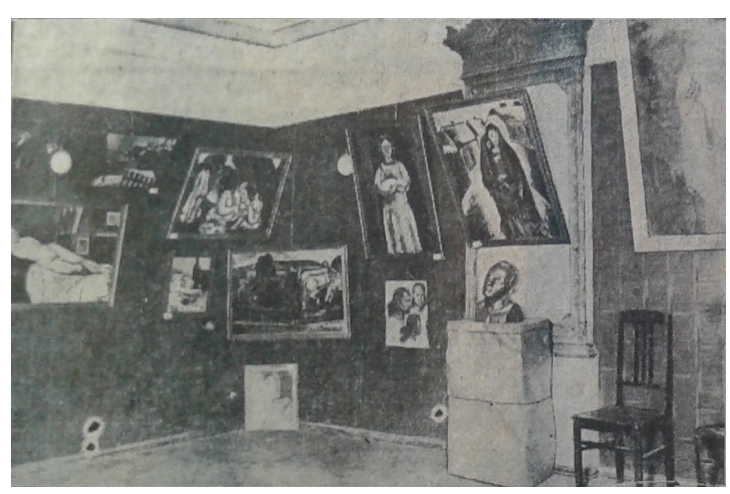

Fig. 6. Fragment of exposition room of Lithuania's and Latvia's Jewish artists exhibition in Kaunas, Сегодня, 1931, issue No. 12, p. 6

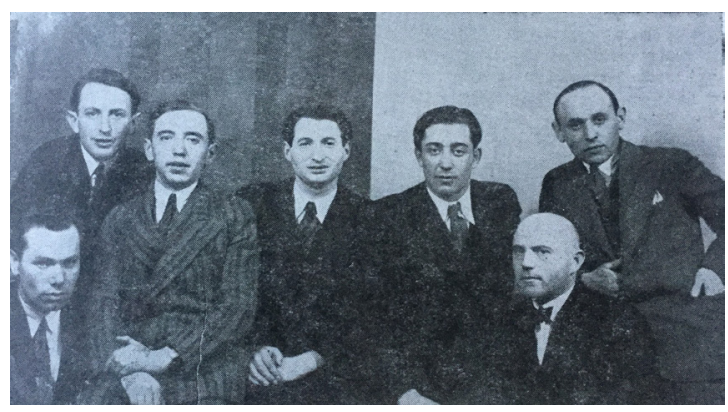

Fig. 7. Group of Lithuania's and Latvia's Jewish artists, seated, from right to left: Sherman, H. Markus, J. Veisbart (Weisbart), Lev Hercmark, Z. Beker; standing: J. Kazlauskas (Jacques Koslowsky), M. Tsesler, Lipshits, Sherenzon, Yofe, Сегодня, 1931, issue No.12, p. 6
The text of the catalogue accompanying the exhibition emphasised the connection of Lithuania's Jewish artists with their homeland, which is an inexhaustible source of "creative power and originality". ${ }^{31}$ It uses the following words to describe Jewish art: "peculiar", or "spontaneous", accentuating the artists' specific taste, and constructing a narrative almost identical to the message of the programmatic text that Noyekh Yitskhok Gotlib published in the literary almanac "Mir Aleyn" in $1930 .{ }^{32}$ The publishing house that issued the almanac, also under the name of "Mir Aleyn", was founded in 1927. The cream of local Jewish writers, artists and other cultural figures gathered around the publishing house. According to Goda Volbikaite, a scholar of Yiddish literature, the programmatic text of "Mir Aleyn" conveys "the type of the Lithuania's Jewish writer who is no longer omnipotent, but who must gather his last strength before extinction", 33 but in speaking of artists, this description is not relevant: the artists' work is not limited by the language barrier that prevented Jewish Yiddish-language writers from reaching out to their fellow countrymen who were becoming more and more integrated into Lithuanian culture. The catalogue text applies the role of the lingua franca to art: "the language of art has been the most influential and has always forged the strongest bond between people of even the most diverse cultures"34 and "at last, the threads will be drawn together that will recede over all borders into true art, which knows no national or political bounds".35

The exhibition, which ran until 15 December, attracted a great deal of interest from the public and positive critical acclaim in the periodical press in Lithuanian, Russian and Yiddish. V. Bičiūnas, ${ }^{36}$ I. Šlapelis, ${ }^{37}$ Reuven Rubinstein, ${ }^{38}$ Kajetonas Sklèrius, ${ }^{39}$ and J. Veisbart (Weisbart) ${ }^{40}$ wrote reviews of the exposition. As promised in the introduction to the catalogue, this exhibition was "the beginning of a whole series of exhibitions". ${ }^{41}$ It may not have caused as much of a stir as hoped, but there was a continuation of this initiative: in 1931, Kaunas welcomed an international exhibition of Lithuanian and Latvian Jewish artists (Fig. 8). The Latvian colleagues were well ahead of the Lithuanians in terms of collective union: they had been organising joint exhibitions 
since 1920, and in 1927 the Latvian Jewish Artists' Society became a strong impetus for national artists to engage in creative work. The "free, unorganised" group of Lithuania's Jewish artists did not seem to be a significant problem to one of the main initiators of the exhibition of Jewish artists from the neighbouring countries, the art historian and philosopher Johan Veisbart (Weisbart) (c.1895-1934): according to him, Lithuania's Jewish artists "feel quite free when they depict something, they are unrestrained" 42 and this encourages them to create.

On 3 January 1931, the former Vincas Kudirka Library opened a group exhibition of Lithuania's and Latvia's Jewish art. ${ }^{43}$ Representatives of the Lithuanian Jews were Lejja Batvinskaitè, Zale Beker, Moses Tsesler, Sholom Feigenzon, Max Leiba Ginsburg, Yitskhok Yofe, Ch. Kacas, Jokūbas (Jankelis) Kazlauskas (Jacques Koslowsky), Levinsonas, H. Markus, Abraom Sherenzon, and Yehezkel Streichman, while the "landing party" of Latvian Jewish artists consisted of Yosel Baron, Moshe Dembo, Solomon Fleishman, Arij Girnun, Lev Herzmark, Ārons (Arkādijs) Naišloss, Moses Parparov, Isaak Sherman, David Skolnik and Helena Lipshits-Skolnik. ${ }^{44}$ Justinas Vienožinskis identifies that which he considers to be the characteristic features and elements of all Jewish artists:

"Something that the Jews in this exhibition have in common, and is perhaps characteristic of modern Jewish painting in general, is a predilection for grey,

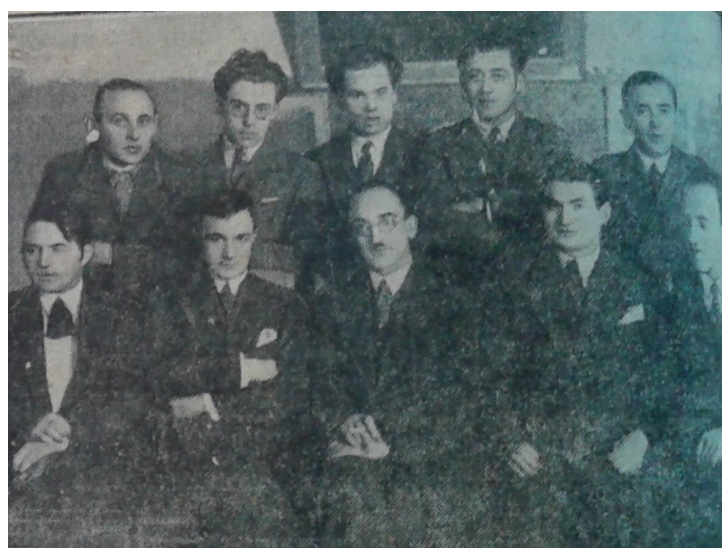

Fig. 8. A group of Lithuania's Jewish artists, from right to left: I. Yofe, Z. Beker, M. Tsesler, H. Markus, J. Kazlauskas (Koslowski), Y. Streichman, J. Lipshits, Lite (ליט ), vol. 2, ed. Ch. Leikowicz, Tel-Aviv: I. L. Peretz Publishing House, 1965, p. 528 dark and sombre, as if depressed, colour chords; a less modest treatment of drawing and form; and a particular inclination towards the broken, "deformed" shapes of Chagall, Zack and other more prominent Jewish artists, which are so close to the ideology of Jewish artists - as if they were a voice of protest of an aching, troubled conscience". 45

\section{NEEMIYA ARBIT BLATAS' ART GALLERY}

The two cases of the Jewish artists' gathering that we have discussed above are linked by a purposeful effort to unite artists on a national basis, as well as to summarise their achievements and to present them to the public, regardless of their level of education or artistic style. The Art Gallery of Neemiya Arbit Blatas, which was a significant launch into the life of interwar Kaunas, was formed on a different ideological - basis. It emphasised modernity, both in terms of the very institution and its content, and although this was not the gallery's main intention, it became a focal point for international Jewish artists.

The name of undoubtedly the most prominent Lithuanian Jewish artist and public figure of the interwar period, Neemiya Arbit Blatas (1908-1999) associates with the bohemian milieu of the École de Paris: he is considered to be the youngest, and probably the last, member of the art movement. Arbit Blatas, who arrived in Paris in 1926, soon joined the diverse chorus of artists, expanding his circle of acquaintances with each passing year, and befriending art world greats such as Pablo Picasso, Chaim Soutine, Maurice Utrillo and many others. He often visited Kaunas (he returned every year from 1926 to 1933 , and more than once a year), never missed the opportunity to show his work in both group and solo exhibitions, became close friends with modern Lithuanian artists, and in the period from 1929 to 1931, thanks to his articles in the magazine "New Word", he became almost the Parisian bohemian attaché to Lithuania. Assimilation, acquaintances, career, ambitions, and creativity shaped Arbit Blatas' image as a modern artist. However, one of the main arguments used to illustrate Arbit Blatas' modernity, and especially its dissemination in Lithuania, 
is the private Art Gallery that he founded in Kaunas, which was open from September 1932 to May 1933.

Arbit Blatas' biography and oeuvre have been widely studied, ${ }^{46}$ and the Art Gallery that he founded has received its own attention as a unique phenomenon of interwar cultural life: in her articles, Vilma Gradinskaite $^{47}$ has reconstructed the chronology of its exhibitions in the context of the other expositions of the time, and Giedre Jankevičiūte, ${ }^{48}$ in her research, highlighted the specific circumstances of its creation, as well as the significance and place of the institution.

In searching for the origins of Arbit Blatas' gallery, we should start with his studies at the Académie Lhote in Paris between 1927 and 1928. The environment at the Academy inspired Arbit Blatas' first steps in the dissemination of modern art. One of the most popular private art academies in Paris, it was charged with an atmosphere of avant-garde art-making and the authority of the Cubist André Lhote (1885-1962). In the corridors of the academy, one could find students from all continents, from all corners of the world, speaking different languages. Friendships that forged through the ideas

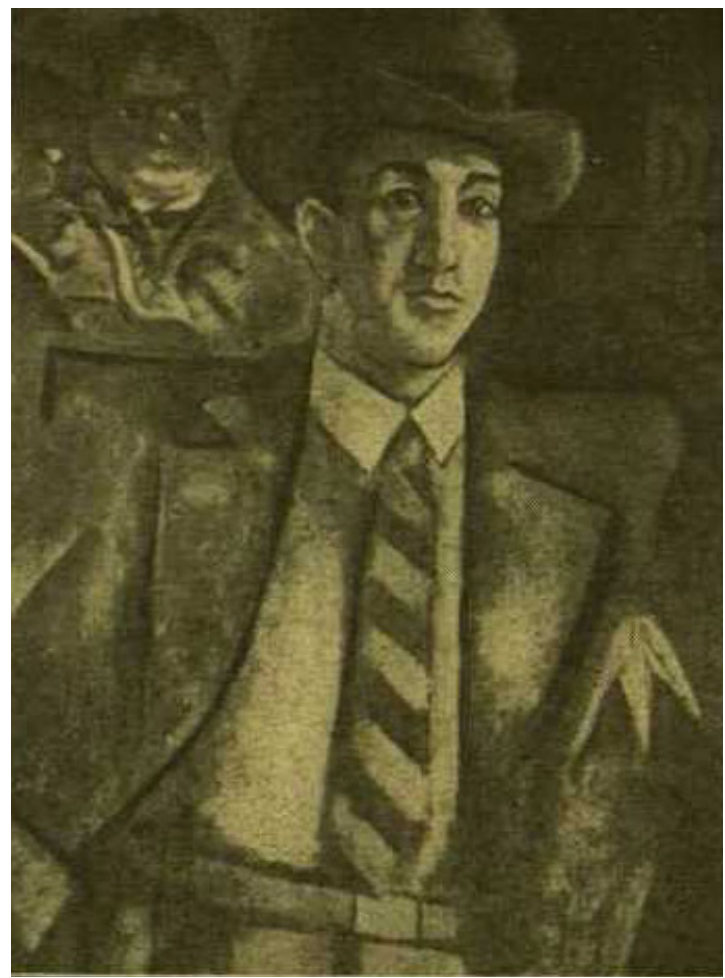

Fig. 9. Neemiya Arbit Blatas. Portrait of a Young Man, Mùsu dienos, 1928, issue No.16, p. 6 of modern art also developed into real projects: the close friendship between the two Jewish expatriates, Neemiya Arbit Blatas and Samuel Greenburg, ${ }^{49}$ was one of them.

From 4 to 16 September 1928, the two artists held a joint exhibition in the hall of the Kaunas Employment Service. ${ }^{50}$ The small exposition, mainly showing portraits and caricatures, ${ }^{51}$ was not lacking in great ambition, boldly presenting avant-garde Parisian sentiments. Poet and journalist Kazys Binkis (1893-1942) also noticed these intentions: the editor of the "Our Days" illustrated weekly magazine on literature, art and society, being the rebellious former leader of the "Four Winds" literary breakthrough, was not indifferent to modern and ambitious ambitions, and in the pages of his magazine, he devoted the most attention of any Lithuanian periodical of the time to the exhibition and its authors $^{52}$ (the daily "Di Yidishe Shtime" also closely followed the performance of two young Jewish artists, ${ }^{53}$ and published a number of their artworks). ${ }^{54}$ The reproductions published in the magazine give an insight into the works by Arbit Blatas and Greenburg and their styles ${ }^{55}$ (Fig. 9-11). Both artists were

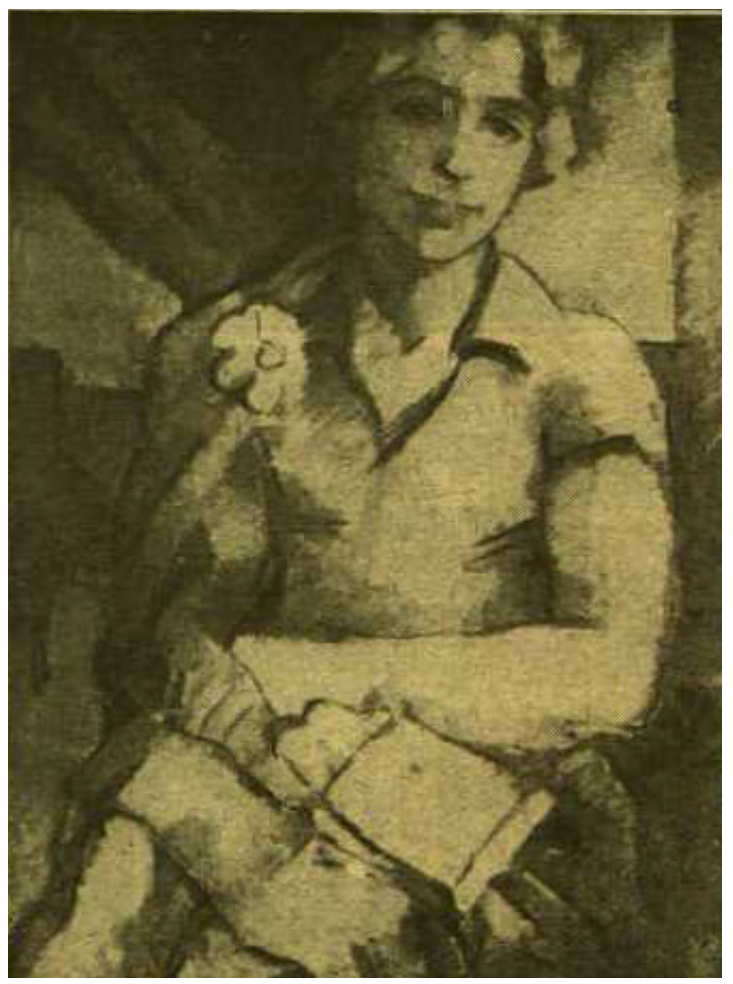

Fig. 10. Samuel Greenburg. Portrait, Mūsų dienos, 1928, issue No. 16, p. 6 
strongly influenced by Lhote at the time, which often expressed in a cubist style.

After the exhibition, the young artists went their separate ways: Arbit Blatas stayed in Paris and Greenburg returned to Chicago around 1929. In 1931, Greenburg opened the Little Gallery in Chicago; a year later, Arbit Blatas established the Art Gallery in Kaunas. ${ }^{56}$ In the summer of 1931, the Little Gallery opened its doors in the Auditorium Tower building in downtown Chicago. Greenburg, who founded the gallery, was joined by Alexander Raymond (Sandor) Katz (1895-1974), also a modern Chicago artist, to run the gallery. Founded during the difficult years of the Great Depression, the small art gallery had to find its niche in Chicago's rather active exhibition life. The gallery represented young modernist artists, often serving as a venue for their first exhibitions. Greenburg identified the aim of "acquainting the public with those Chicago artists who, in avoiding the royal road of formulas that sell, have found themselves on paths inaccessible to the many"57 to be one of the main goals of the institution. To facilitate the public's perception of the work by modern artists, the gallery organised lectures free of charge, featuring talks by artists or

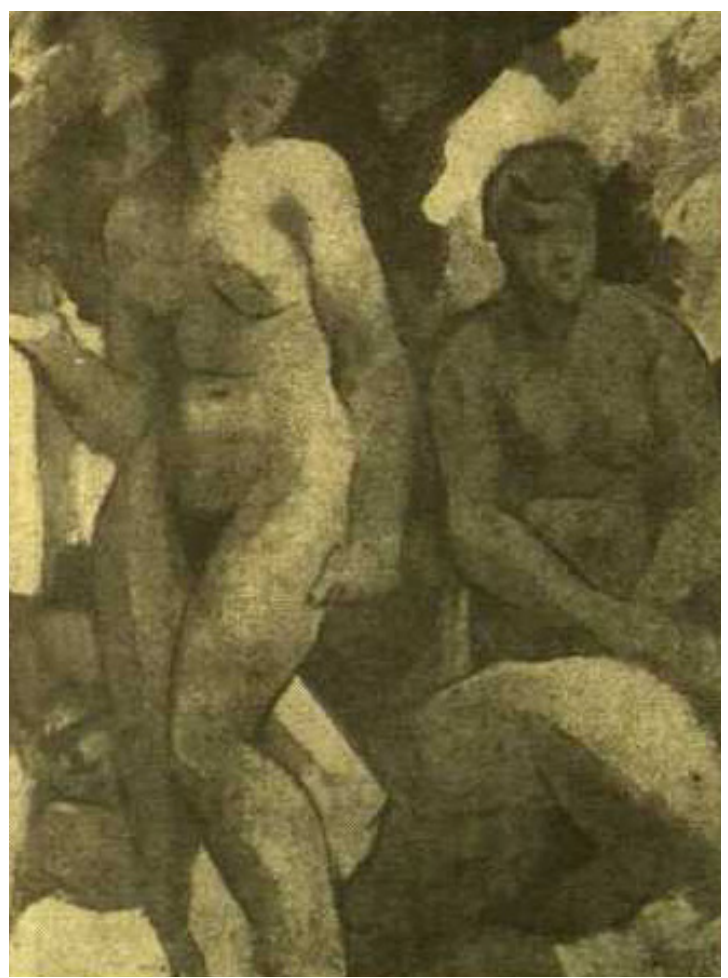

Fig. 11. Samuel Greenburg. Composition, Mūsu dienos, 1928, issue No. 16, p. 6 art experts. The gallery began with an exhibition by the famous Chicago painter Fred Biesel, and by the time it closed in August 1933, it had held the following exhibitions: in 1931 - of paintings by Belle Goldschlager Baranceanu; in 1932 - an exhibition of lithographs by George Grosz, drawings by Greenburg, watercolours by Herbert Lewis; in 1933, a group exhibition of woodcuts by Charles Turzak and a group exhibition "Heads" by Gertrude Abercrombie, Fritzi Brod, Paul Kelpe and Helen Mann. The gallery closed with an exhibition of sketches by Enrico Glicenstein. In 1933, Greenburg handed over the directorship of the gallery to his colleague A. R. Katz, who announced its closure. ${ }^{58}$

At that time, Arbit Blatas joined forces with fellow Lithuanian artists Antanas Gudaitis, Adolfas Valeška, Juozas Mikènas, Vytautas Kazimieras Jonynas, Stasys Ušinskas, and others to establish a modern art gallery. The planning probably started in Paris, where the young artists were studying, but financial and conceptual disagreements led to a divergence of paths among the main participants. Arbit Blatas did not postpone the opening of the gallery, while the Lithuanian artists formed the modern movement Ars. ${ }^{59}$

Thus, despite all the difficulties, in the beginning of organising the activities of the Art Gallery, on 4 September 1932, in the former premises of the Kaunas Employment Service ${ }^{60}$ at the crossroads of Gedimino and Nepriklausomybès streets, Arbit Blatas presented his first exhibition. The gallery not only housed an exhibition hall, but also a small library, which offered visitors the latest periodicals and books on art and literature. After the collapse of the original idea for the gallery, Arbit Blatas' main task was to organise, in a short space of time, an exhibition of modern art reflecting his aims and his vision of modern art. The incoherent start of the institution's operation affected the first exhibition: "the 'Gallery"s organiser had to urgently invite new people, even from abroad, to replace those who had refused. The invitees responded, but because of the haste, the exhibition turned out to be far from what it could have been (even in the same cramped space)". ${ }^{61} \mathrm{He}$ filled the exhibition hall with artworks by local and foreign artists of mainly Jewish origin, 
including his own works and those by M. Band, Z. Beker, I. Kulvianski, H. Markus, Cherne Percikovichiute (Černė Percikovičiūtè), J. Lipshitz, Jokūbas (Jankelis) Kazlauskas (Jacques Koslowsky), E. Streichman (1906-1993), and E. Levinsonas, as well as sculptures by M. Tsesler and I. Yofe. With the exception of Ch. Percikovichiute and I. Kulvianski, other local Jewish artists had participated in group Jewish exhibitions. Representatives of foreign artists were Emanuel Mane-Katz (1894-1962) and Issachar Ber Ryback; the exhibition also displayed paintings by René Dufour (1896-1974), “Canonicus” prints by Pietro Annigoni (1910-1988), and the works by the unidentified artist Gorioup. Several Lithuanian artists also took part in the exhibition: Mečislovas Bulaka, S. Ušinskas and A. Valeška. The exposition ran until November, and in October it was supplemented by works by Latvian artists. ${ }^{62}$

Jewish artists also dominated the gallery's subsequent activities, with the only exhibition not related to them being a collection of Japanese engravings by the artist Mstislavas Dobužinskis, presented on 12 November. On 18 December, it opened the exposition by the US-based Jewish artists F. Blumberg-Kopman and her husband Benjamin D. Kopman (1887-1965). The Art Gallery entered the new year of 1933 with an exhibition by the Latvian artist, caricaturist and scenographer Mikhail Io (real name Meyer Joffe, 1895-1960), which opened on 31 December 1932. This was followed again by a collective exhibition of almost exclusively Jewish artists. The gallery invited Liuba Kenskytè-Šaltuperienè (Luba Kenski-Shaltuper, 1901-1984) from Kaunas, Zelman Utkes (1892-1944) from Paris, Eric Goldberg (1890-1969), who was already living in Canada at the time, and the German Rudolf Hopp (Rudi Gopas, 1913-1983) from the Klaipeda region, to join the Lithuanian Jewish artists who had taken part in the gallery's first exhibition and Mikhail Io, who had left a few of his artworks behind. ${ }^{63}$

On 26 February, the gallery invited viewers to the exhibition by one of the most popular Kaunas photo studios "Zinaida". 64 Founded in 1931, the atelier, whose head was the photographer Zinaida Bliumentaliene, was popular among Kaunas high society circles. The exhibition was dominated by portraits of celebrities and photographs of State Theatre performers: both portraits and different characters that they played. The Art Gallery crowned its exhibition season by a solo exposition of Arbit Blatas' oeuvre, which opened on 19 March 1933: ${ }^{65}$ the retrospective show featured works from various stages of the artist's career. On 1 May 1933, after Arbit Blatas' departure back to Paris, the gallery closed, and Arbit Blatas did not participate in any exhibitions in Lithuania until the very Second World War.

During the almost nine months of its activity, the Art Gallery held 8 exhibitions. Visitors had the opportunity to get to know artists from different countries and to become acquainted with different art forms and styles. The ongoing exhibitions brought some dynamism into the life of the temporary capital and encouraged the organisers of other exhibitions to work harder. Summing up the work of the gallery and the participants in the exhibitions, three quarters of them were Jewish artists. Arbit Blatas' ambition to broaden the boundaries of nationality and concentrate on the stylistic principles of modernism was only partially realised.

\section{References}

"Apžvalginè dail. Arbitblato darbų paroda“. Lietuvos žinios issue no. 62 (March 17, 1933): 5.

Arbit Blatas (1908-1999). Compiled by Ilona Mažeikienè, Vilnius: Lietuvos dailès muziejus, 2019.

Arbitblatas. Sugrižimas j̇ tèvynę. A catalogue of artworks given as a gift to the Lithuanian nation by Ms. Regina Resnik Blatas, compiled by Ilona Mažeikienè, Vilnius: Lietuvos dailès muziejus, 2011.

Bukauskaitė, E. "Lietuvos žydų dailininko Juozapo Levinsono-Benari veikla tarpukariu“. Menotyra Vol. 19, issue no. 1 (2012): 47-61.

"Žydų daile žydų politinès autonomijos laikotarpiu Lietuvoje 1919-1924 m.“. Menotyra Vol. 27, issue no. 1 (2020): 107-123.

"Dailininko B. Cukermano kūrinių paroda“. Laisve issue no. 237 (November 14, 1920): 3.

Dmitreva, M. "Traces of Transit. Jewish Artists from Eastern Europe in Berlin“. Osteuropa, 2008, 143-156. . "Announces Closing of Little Gallery". Chicago Sunday Tribune, August 20, 1933, 4.

Eleanor, Jewett. "New Chicago Art Gallery to Show Work of Local Artists". Chicago Sunday Tribune, September 6, 1931, 7 . 
"Fun der oysshtelung fun di yunge ydishe kinstler in Kovne“. Di yidishe shtime issue no. 207 (1928): 8.

Gotlib, Noakh Itskhak: Mir aleyn, Mir aleyn. Kovne: Mir aleyn, 1930, 45-48.

Gradinskaite, Vilma. "The First Exhibitions of Jewish Artists in Kaunas (1920-1940) from the Art Critic's Perspective". IGGUD Selected Essays in Jewish Studies Vol. 3 (2007): 115-129.

. Modernaus meno galerija Kaune. Arbitblatas (1908-1999). Compiler Ilona Mažeikienè. Vilnius: Lietuvos dailès muziejus, 2019, 203-212.

. "Neemiya Arbit-Blatt's Modern Art Gallery in Interwar Kaunas". Pinkas, Annual of the Culture and History of East European Jewry Vol. 1, Vilnius: The Centre for Studies of the Culture and History of East European Jews, 2006, 169-180.

. "Tarp tradicijos ir modernumo: litvakų tautinio tapatumo paieškos ir kaita“. Kultūrologija Vol. 16 (2008): 185-196.

Grigoravičiūtè, Akvilè. "Jidiš literatūra tarpukario Lietuvoje (1918-1940): savasties paieškos“. Colloquia 29 (2012): 38-62.

Yor eyn - yor oys. Yorbukh-kalendar. Ed. Natanas Jonasevičius. Kaunas: Žydų Istorijos-Etnografijos draugija Lietuvoje, 1939.

Jakštas, A. "B. Cukermano paveikslų paroda“. Laisvè issue no. 2 (December 2, 1920): 4.

Jankevičiūte, Giedrè. Žydų dailininkai tarpukario Lietuvos meninëje kultūroje. Abipusis pažinimas: lietuvių ir žydu kultūriniai saitai. Compiled by J. Šiaučiūnaitè-Verbickienè. Vilnius: Vilniaus universiteto leidykla, 2010, 69-102.

Jankevičiūte, Giedrè. Daile ir valstybè. Dailès gyvenimas Lietuvos Respublikoje 1918-1940. Kaunas: Nacionalinis M. K. Čiurlionio dailès muziejus, 2003.

"Kauno kronika“. Laisvè issue no. 160 (July 22, 1921): 4.

Kolektyvinès žydų lietuvių ir latvių dailininkų meno parodos katalogas. Kaunas, 1931.

Kozlovsky, Yakob. Yidishe kinstler fun Lite. Ed. Ch. Leikowicz. Lite vol. 2 (1965): 534, Tel-Aviv: I. L. Peretz Publishing House.

"Kronika". 7 meno dienos issue no. 92 (February 24, 1933): 14.

Kuban, Zeynep, Wille, Simone. André Lhote and His International Students. Innsbruck: Innsbruck university press, 2020.

Kveytn. Red. David Kot. Panevezh, 1922.

Laučkaitè, Laima. Vilniaus daile Didžiojo karo metais. Vilnius: Lietuvos kultūros tyrimų institutas, 2018.

Liekis, Šarūnas. State Within a State? Jewish Autonomy in Lithuania 1918-1925. Vilnius: Versus Aureus, 2003.

Lietuviu meno parodos katalogas. Kaunas, 1921.

Lietuvos žydai: istorine studija. Compiled by V. Sirutavičius, D. Staliūnas, J. Šiaučiūnaitè-Verbickienè. Vilnius: Baltos lankos, 2012.

Mulevičiūtè, Jolita. Modernizmo link. Dailès gyvenimas Lietuvos Respublikoje 1918-1940. Kaunas: Nacionalinis M. K. Čiurlionio dailès muziejus, 2001.

"N. Arbitblato ir S. Greenburgo paveikslų paroda“. Mūsų dienos issue no. 16 (1928): 6.

"Oysshtelung fun ydishe kinstler". Di ydishe shtime issue no. 211 (1928): 7.
"Pirma Lietuvos žydų menininkų kūrinių paroda [katalogas]". Kaunas, 1929.

Plafon, Yankev. "Sara Gorsheyn“. Vispe, 1924, 36.

Sefer zikaron le-esrim ve-shalosh kehilot she-nehrevu be-ezor Svintsian. Ed. Shimon Kanc, Tel Aviv, 1965, col. 481.

Shapiro, Chaim. "Dr. Leo Deutschlander. Father of the Bais Yaakov Movement: Forty Years After His Passing“. Jewish observer/Summer, 1975, 14-17.

Shlyakhn: Zamblbukh far literatur. Kovne, 1932.

Spector [Vytautas Bičiūnas]. "S. Goršenaitès skulptūros paroda“. Gairés issue no. 5 (1923): 313-314.

Spector. "Pirma Lietuvos žydų meno paroda“. 7 meno dienos issue no. 46 (1929): 9.

V. B. [Vytautas Bičiūnas]. "Rudens sezono parodos“. Židinys issue no. 8-9 (1932): 168-169.

Veisbart, J. "Di ershte oysshtelung fun di Yidishe kinstler in Lite“. Mir aleyn, Kaunas, 1930, insert between p. 36-37.

Vienožinskis, Justinas. "Kolektyvinè Lietuvos ir Latvijos žydų dailininkų meno paroda“. Naujoji Romuva issue no. 3 (January 18, 1931): 67.

Weissbarth, J. "Žydų meno paroda Kaune“. Vairas issue no. 3 (1931): 354-358.

Volbikaite, Goda. "Jidišakalbių literatūrinių sambūrių savikūra tarpukario Kaune: Vispe ir Mir Aleyn“. Darbai ir dienos issue no. 57 (2012): 65-83.

\section{Notes}

1 Giedrè Jankevičiūtė, "Žydų dailininkai tarpukario Lietuvos menineje kultūroje”, Abipusis pažinimas: lietuvių ir žydu kultūriniai saitai, compiled by J. Šiaučiūnaitè-Verbickienè (Vilnius: Vilniaus universiteto leidykla, 2010), 69-102.

2 Lietuviu meno parodos katalogas (Kaunas, 1921).

3 Vilma Gradinskaite, “Tarp tradicijos ir modernumo: litvakų tautinio tapatumo paieškos ir kaita", Kultūrologija 16 (2008), 185-196.

4 "The First Exhibitions of Jewish Artists in Kaunas (1920-1940) from the Art Critic's Perspective”, IGGUD Selected Essays in Jewish Studies 3 (Jerusalem, 2007), 115-129.

$5 \quad$ Kveytn, red. David Kot (Panevezh, 1922).

6 Shlyakhn: Zamblbukh far literatur (Kovne, 1932).

7 Žydų tautos taryba ir Seimo Žydų frakcija, folder 1 Žydų tautos taryba, LCVA, f. 620.

8 The post was also known as the "Minister without Portfolio", because the ministry was never established, only a chancellery. For more on the structure and activities of the Jewish People's Council, in Š. Liekis, State Within a State? Jewish Autonomy in Lithuania 1918-1925 (Vilnius: Versus aureus, 2003).

9 Žydų tautos tarybos prašymas Kauno miesto ir apskrities komendantui, 1920 m. lapkričio 10 d., LCVA, fond 620, folder 1, file 34, p. 51 .

10 Ibid.

11 "Dailininko B. Cukermano kūrinių paroda", Laisvè issue No. 237 (November 14, 1920), 3. 
12 A. Jakštas, "B. Cukermano paveikslų paroda", Laisvé issue No. 2 (December 2, 1920), 4.

13 Letter from the Section of Culture to J. Budko, December 27, 1920, Lithuanian Central State Archives, fond 620, folder 1, file 43 , p. 43 .

14 Struck's artworks were published together with Herbert Eulenberg's texts in 1916 in the book Skizzen aus Litauen, Weissrussland und Kurland, and in 1920, he drew illustrations for the book by Arnold Zweig Das Ostjüdische Antlitz.

15 Letter from the Head of the Culture Section to Consul B. Giršavičius, February 4, 1921, Lithuanian Central State Archives, fond 620, folder 1, file 81, p. 45.

16 Letter from the Head of the Culture Section to Consul B. Giršavičius, December 23, 1920. Lithuanian Central State Archives fond of Jewish National Council of Lithuania and the Jewish Fraction of the Seimas, fond 620, folder 1 , file 68 , p. 33 .

17 "Kauno kronika", Laisve issue No. 160 (July 22, 1921), 4.

18 Surname spelling versions were the following: Gorschen, Gorschein, Gorszejn, Gorshteyn.

19 Lithuanian Central State Archives, fond 1264 Municipality of the Panevezžys town, folder 3 Schedule of files of personal documents for obtaining an internal passport, file 6836, page 2 .

20 "Yankev Plafon". Sara Gorsheyn, Vispe (1924), 36.

21 Ibid.

22 Spector, "S. Goršenaitès skulptūros paroda", Gairès issue No. 5 (1923), 313-314.

23 Goršenaite lived in Paris from 1924 to 1928 and studied at the École Nationale des Beaux-Artes. After returning to Lithuania in 1928-1929, she took part in the first exhibition of Lithuanian Jews. In 1929, the sculptor went back to Paris. She established herself in the art capital of the time and was quite successful. In 1931, the artist was noticed by the art historian, critic and painter Otto Schneid (1900-1974), who wanted to include her in a forthcoming dictionary of modern Jewish artists of the 20th century, Die Juden und die Kunst. In 1932, the Salon des Indépendants exhibition featured two of Goršenaitès plaster cast works: a portrait of the artist Solomon Lerner and a head of a young Greek man. From 20 May to 4 June 1933, the Jeune Europe gallery-library in Paris (46 rue Vavin) hosted an exhibition of Goršenaite’s sculpture and the Mon Village series of paintings by Solomon Lerner (1890-1963). M. Band also took part in exhibitions at the gallery-library founded by the Italian writer Antonio Aniante (Antonio Rapisarda, 1900-1983). The Second World War caught Goršenaitè in Kaunas. After surviving the horrors of the concentration camps, she remained in Poland after the liberation in 1945 and settled in Lodz, where she continued her career as an artist. She actively participated in exhibitions. In 1957 she emigrated to Israel, settling in a suburb of Tel Aviv.

24 Smithsonian Institution, Archives of American Art, Eva Lee Gallery records, box1, folder 34 [Internet access at: https://www.aaa.si.edu/collections/eva-lee-gallery-records-8866/1/box-1-folder-34, accessed on 2021.04.10]. 25 In 1910, J. B. (Jsrael Ber) Neumann (1887-1961), gallerist, art dealer and publisher, established his first gallery in Berlin, with branches operating in Bremen, Düsseldorf and Munich in the 1930s and 1940s. After emigrating to the United States in 1923, he continued to develop his gallery activities. While still living in Germany, he founded the "Gehenna Press" publishing house and published the art periodicals "Bilderhefte" (1920-1922) and "Artlover" (1926-1945, 1959);

26 The artist returned to Lithuania in the form of her own artworks in 1932 for a joint exhibition with her husband Benjamin Kopman at Neemiya Arbitblat's Art Gallery.

27 Yor eyn - yor oys. Yorbukh - kalendar, red. Natanas Jonasevičius (Kaunas: Žydų istorijos-etnografijos draugija Lietuvoje, 1939).

28 Pirma Lietuvos žydų menininku kūriniu paroda [cata$\log$ ] (Kaunas, 1929).

29 Ibid.

30 Pirma Lietuvos žydų menininku kūriniu paroda [cata$\log$ (Kaunas, 1929).

31 Ibid.

32 Gotlib, "Noakh Itskhak: Mir aleyn", Mir aleyn (Kovne: Mir aleyn, 1930), 45-48.

33 Goda Volbikaite, "Jidišakalbių literatūrinių sambūrių savikūra tarpukario Kaune”, Darbai ir dienos issue No. 57 (2012), 83.

34 Pirma Lietuvos žydų menininku kūriniu paroda [cata$\log$ ] (Kaunas, 1929).

35 Ibid.

36 Spector, "Pirma Lietuvos žydų menininkų paroda", 7 meno dienos issue No. 46 (December 14, 1929), 9.

37 Ign. Šlapialis, "Di malerei- un skulptur- oysštelung”, Di jidiše štime issue No. 289(3077) (December 13, 1929), 9.

38 R. Rubinštein, "Unzere kinstler", Di jidiše štime issue No. 267(3055) (November 19, 1929), 2.

39 R. Ch., "Bei di jidiše kinstler (Fun a gešprech mitn kinstler Škleris)”, Di jidiše štime issue No. 279(3067) (December 03, 1929), 7.

40 J. Veisbart, "Fun unzere kinstleriše kuchus", Di jidiše štime issue No. 283(3071) (December 06, 1929), 5; J. Veisbart, "Di eršte oysštelung fun di jidiše kinstler in Lite", Mir aleyn (Kovne, 1930), 33-37; Joh. Weisbarth, "Meno parodos”, I, Pirma Lietuvos žydų menininkų paroda Kaune, Vairas issue No. 2 (1930), 482.

41 Ibid.

42 Ibid.

43 J. Weissbarth, "Žydu meno paroda Kaune”, Vairas issue No. 3 (1931), 354-358.

44 Kolektyvinès žydų lietuviu ir latviu dailininkų meno parodos katalogas (Kaunas, 1931).

45 "J. Vienožinskis, Kolektyvinè Lietuvos ir Latvijos žydų dailininkų meno paroda", Naujoji Romuva issue No. 3 (January 18, 1931), 67.

46 Arbitblatas. Sugrižimas ji tèvynę: ponios Reginos Resnik Blatas Lietuvos tautai dovanotų küriniu katalogas, compiler Ilona Mažeikienè (Vilnius: Lietuvos dailès muziejus, 2011); ArbitBlatas (1908-1999), compiler Ilona Mažeikienè (Vilnius: Lietuvos dailès muziejus, 2019).

47 Vilma Gradinskaite,, "The Modern Art Gallery of Neemiya Arbit-Blatt in Interwar Kaunas", Pinkas, Annual of the Culture and History of East European Jewry Vol. 1 (Vilnius: The Centre for Studies of the Culture and History of East European Jews, 2006), 169-180; Vilma, Gradinskaite, Modernaus meno galerija Kaune, ArbitBlatas (1908-1999), compiler Ilona Mažeikienè (Vilnius: Lietuvos dailès muziejus, 2019), 203-212.

48 Giedrè Jankevičiūtė, “Žydų dailininkai tarpukario Lietuvos meninèje kultūroje”, Abipusis pažinimas: lietuviu 
ir žydu kultūriniai saitai, compiler J. Šiaučiūnaitė-Verbickienè (Vilnius: Vilniaus universiteto leidykla, 2010), 69-102.

49 Samuel Greenburg (1905-1980), who came to Paris from Chicago, was born in Uman, Ukraine. His family emigrated to the United States of America around 1910. He studied art at the University of Chicago and at the Bezalel Art School in Jerusalem. He worked as a caricaturist for newspapers in Egypt, Palestine and later Chicago. 50 The realisation of this idea was probably prompted not only by the artists' professional ambitions, but also by the circumstances of their personal lives: Greenburg and Leah Rozalsky, who came originally from Kaunas and was a student of philology at the Sorbonne University, were married in Paris in the summer of 1928.

51 "N. Arbitblato ir S. Greenburgo paveikslų paroda", Mūsu dienos issue No. 16 (1928), 6.

52 The friendly relationship between the magazine and these creators is also visible from the caricatures that Greenburg drew of K. Binkis and Antanas Rimydis (one more caricature, of the actor Kačinskas, was published in the magazine "Naujasis žodis" of 1928, issue No. 1, p. 10).

53 "Oysshtelung fun ydishe kinstler", Di ydishe shtime issue No. 211 (1928), 7.

54 "Fun der oysshtelung fun di yunge ydishe kinstler in Kovne”, Di yidishe shtime issue No. 207 (1928), 8.

55 "N. Arbitblato ir S. Greenburgo paveikslų paroda", Mūsu dienos issue No. 16 (1928), 6.

56 It should be noted that it was not only Arbit Blatas and Greenburgh who had hopes of spreading modern art trends in their galleries. Also, Dorothea Foster (Dorrit) Black (1891-1951), an Australian who studied at the Académie André Lhote from around 1928-1929, returned to Sydney in 1931 and founded the Modern Art Centre, the first art gallery in Australia devoted solely to modern art. The Centre, which operated until 1933, was a major influence on the formation of modern Australian art. For more on the spread of Lhote's influence in Zeynep Kuban,
Simone Wille (eds.), André Lhote and His International Students (Innsbruck university press, 2020).

57 Eleanor Jewett, "New Chicago Art Gallery to Show Work of Local Artists", Chicago Sunday Tribune (September 06, 1931), 7 .

58 Eleanor Jewett, "Announces Closing of Little Gallery", Chicago Sunday Tribune (August 20, 1933), 4.

59 More about the establishing of the gallery in Giedrẻ Jankevičiūtė, "Žydų dailininkai tarpukario Lietuvos meninèje kultūroje”, Abipusis pažinimas: lietuviu ir žydu kultūriniai saitai, compiler J. Šiaučiūnaitè-Verbickienė (Vilnius: Vilniaus universiteto leidykla, 2010), 69-102.

60 The space was very familiar to the artist: in 1927 he had held an exhibition here with A. Šimkūnas, and in 1928 - with S. Greenburg. The premises did not host exhibitions so often: in addition to the two already mentioned, it also welcomed exhibitions of paintings by Jonas Mackevičius and sculpture by Juozas Zikaras (October 1928), as well as exhibitions of watercolours by Kajetonas Sklèrius and ceramics by Vytautas Brazdžius (from 19 September to 13 October of 1929).

61 V. B. [Vytautas Bičiūnas], "Rudens sezono parodos", Židinys issue No. 8-9 (1932), 168-169.

62 Aleksandra Bel̦cova (1892-1981), Romans Suta (1896-1944), Jānis Liepiņš (1894-1964), Francisks Varslavāns (1899-1949), Isaak Sherman (1907-1951), Jānis Cieliavs (Cielava, 1890-1965) and Moshe Dembo. The gallery also supplemented the exposition with works by Rimtas Kalpokas (1908-1999), Aleksandr Benois (18701960), and F. Blumberg-Kopman.

63 More about the activities of N. Arbit Blatas' gallery in Vilma, Gradinskaite, "Modernaus meno galerija Kaune", ArbitBlatas (1908-1999), compiled by Ilona Mažeikienė (Vilnius: Lietuvos dailès muziejus, 2019), 203-212.

64 "Kronika", 7 meno dienos issue No. 92 (February 24, 1933), 14.

65 "Apžvalginè dail. Arbitblato darbų paroda", Lietuvos žinios issue No. 62 (March 17, 1933), 5.

\section{Evelina BUKAUSKAITE}

Vilniaus dailès akademija, Vilnius, Lietuva

\section{ŽYDŲ MENININKŲ SAMBŪRIAI TARPUKARIO LIETUVOJE}

Santrauka

Pagrindinis šio straipsnio tyrimo objektas - tarpukario Lietuvos žydų dailininkai ir jų pastangos vienytis. Analizuojamas žydų menininkų siekis burtis ị grupes, reprezentuoti ir pristatyti savo dailę, išlaikyti tautinị identitetą. Supažindinama su pagrindiniais dailininkų sambūrių organizatoriais, dalyviais, rengimo aplinkybėmis ir tikslais. Aptariami trys atvejai: Žydų tautos tarybos Kultūros sekcijos instituciniu lygmeniu vykdyta kultūros politika, visuomeniniu pagrindu susibūrę žydų menininkai ir Neemijos Arbitblato Meno galerija, kaip unikali tarpukario Lietuvos 
parodų erdvè, daugiausia eksponavusi žydų menininkų kūrybą. Tyrime akcentuojamas ne meninis palikimas ar jo vertė, bet žydų menininkų kultūrinio gyvenimo procesai tarpukario Lietuvoje.

Reikšminiai žodžiai: žydų dailè, meno sambūriai, meno parodos, Lietuva, tarpukaris.

PhD of History and Theory of Arts programme in Vilnius Academy of Art, Vilnius, Lithuania. The main field of research concentrates on Jewish Art of the Interwar Period in Lithuania.

E-mail: bukauskaite.evelina@gmail.com 